\title{
A CROSS-LINGUISTIC ANALYSIS OF THE WRITING OF PROSPECTIVE FIRST YEAR STUDENTS IN XHOSA AND ENGLISH
}

Zannie Bock \& Phakamani Dadlana

University of the Western Cape

This article aims to characterize typical linguistic and discourse features of academic writing in Xhosa and English among prospective Xhosa-speaking students at the University of the Western Cape so as to account for strengths and weaknesses in the writing and provide possible 'points' for pedagogic intervention. It presents an analysis of a sample of entrance essays written by these students in English and Xhosa. The analysis is in terms of a framework which considers aspects of argument, register and syntax. It aims to highlight strengths and weaknesses in student writing and to ascertain the extent to which these characteristics are language-specific or cross-linguistic. The results of the analysis suggest that the ability to argue coherently in an appropriate register is the defining mark of good writing in any language, and that control over the syntax of the language is particularly important for these students when writing in English. The ability to write well, like certain aspects of style, seems to be a generic ability and affects students' performance in both languages.

Die doel van hierdie artikel is om tipiese linguistiese en diskoerskenmerke van die akademiese skryfwerk in Xhosa en Engels van voornemende Xhosasprekende studente aan die Universiteit van die Wes-Kaap te beskryf. Hiermee word gepoog om die sterktes en leemtes in die studente se skryfwerk te verantwoord en om bepaalde riglyne vir pedagogiese intervensie te beskryf. Die artikel sluit ' $n$ analise in van 'n aantal toegangsessays wat deur hierdie studente in Engels en Xhosa geskryf is. Die analise is gedoen aan die hand van ' $n$ raamwerk wat aspekte van argumentasie, register en sintaksis in aanmerking neem met die oog daarop om die sterktes en leemtes in studenteskryfwerk uit te lig en om vas te stel tot watter mate hierdie eienskappe taalspesifiek of kruislinguisties is. Die resultaat van die analise dui daarop dat die vermoë om koherent in 'n bepaalde register te argumenteer die onderskeidende kenmerk is van goeie skryfwerk in enige taal en dat beheer oor die sintaksis van die taal veral belangrik is vir hierdie groep studente as hulle in Engels skryf. Die vermö̈ om goed te kan skryf blyk, net soos sekere stylaspekte, 'n generiese vermoë te wees wat studente se prestasie in beide tale beïnloed.

\section{PROBLEM IDENTIFICATION AND RATIONALE}

The ability of students to write academic essays in English is a critical factor in their success or failure at tertiary level. Over the past few decades, researchers have investigated student writing from a number of different perspectives (e.g. Berkenkotter \& Huckin, 1995, Candlin \& Hyland, 1999, Ivanic, 1998, Lea \& Street, 1999, Leki, 1995, Taylor et.al., 1988) and 
various approaches to the teaching of academic writing have been developed and researched. This wealth of research has given us valuable information about student writing and useful insights into how best to assist students to develop their abilities to write formal academic English. Yet 'problems' in student writing at tertiary level in English and other languages persist.

his research was sparked by the desire to better understand the 'problems' of student writing in a particular context so as to be able more effectively to assist students to develop their academic writing skills. In particular, the researchers felt that not enough sentence level linguistic analysis had been done of the actual writing, specifically the work of Xhosa/English students who come from historically black schools. This research focuses on a textual analysis of the writing of prospective students with Xhosa as a first language at the University of the Western Cape (UWC) in an attempt to identify and describe the kinds of language problems as well as the strengths that typically characterize their writing. It includes a cross-linguistic comparison of writing by the same students in English and Xhosa to ascertain the extent to which the linguistic features and discourse patterns are language specific. By 'discourse patterns', we are referring to distinctive features of the writing which extend over any stretch of text which is used to communicate and which is judged by the receiver to be coherent (Brown \& Yule, 1983, Cook, 1989).

\section{RESEARCH PURPOSE}

The main research question is: 'How can one characterize typical linguistic and discourse features of academic writing in Xhosa and English among Xhosa-speaking students at UWC so as to account for strengths and weaknesses in their writing and provide possible 'points' for pedagogic intervention?'

The research has clear limits. The researchers recognize that examining only the 'product' of student writing gives no access to the many contextual factors that fundamentally shape that writing. In addition, the researchers are both aware of the dangers of operating within a deficit model of student writing, and familiar with the critiques (e.g. Heath, 1983, Street, 1995) of research which does not critically examine the social and cultural practices the writing is embedded in and which fail to challenge the 'hegemony' of Western academic traditions and definitions of literacy. Nevertheless, it seems clear to us that for the foreseeable future, knowledge of the dominant educational genres as well as the ability to write English in a relatively standard, formal and coherent manner will assist students from historically disadvantaged backgrounds both to access social, economic and political power and to challenge these norms if necessary. We believe that to offer students less is likely to confine them to the margins of society and economic powerlessness (see Hasan, 1996, for a sustained argument supporting this position). Within a context of high unemployment where English is the growing lingua franca of business and government, the ability to communicate competently, particularly in English, if it does not guarantee you a job, certainly improves your chances of getting one.

\section{RESEARCH DESIGN}

This analysis is based on a corpus of entrance essays written by prospective first year Xhosa/English bilingual students as part of an alternative admissions process at the beginning 
of 2000 at the University of the Western Cape. The essays were written under test conditions after students had had a short interview with a lecturer. The test paper read:

\section{Answer QUESTION 1 and ONE other question. Write each answer in the language in which the topic is given.}

Do you think universities in South Africa should use English only, or should students have the choice to study through any of the official languages? Why?

Sê of jy voel dat Afrikaans `n bedreigde taal is in die nuwe Suid-Afrika, en gee redes vir jou siening. (Do you feel that Afrikaans is a threatened language in the new South Africa? Give reasons for your answer)

Chaza ukuba ucinga ukuba abantu mabasebenzise isiXhosa esisulungekileyo (pure/

'deep' Xhosa) ezikolweni, koomabonakude nakwezinye iindawo ezisesidlangalaleni (public places) okanye ucinga ukuba mabasebenzise isiXhosa esixutyiweyo (mixed). Nika izizathu zoluvo lwakho.

(Discuss whether you think people should use pure/'deep'Xhosa in schools, TVs, and other public places or do you think they should use mixed Xhosa. Give reasons for your opinion.)

For the purposes of this analysis, we only considered students who chose to answer questions $1 \& 3$.

A sample of 60 essays was randomly selected and each essay was marked by two experienced lecturers who were first language speakers of the language concerned. The markers were given a rating scale with the following categories to refer to when marking, but were not required to mark strictly to this scale: content, organization, vocabulary, language use, mechanics (spelling, punctuation, paragraphing, etc.). In terms of moderation across both languages, one of the Xhosa markers, Phakamani Dadlana, checked through the English marking and was satisfied that similar standards had been applied. From this larger sample, $10 \mathrm{Xhosa} /$ English pairs were selected for closer examination, 6 from a category of 'good' essays (or those with an average mark of $60 \%$ or above) and 4 from a category of 'weak' essays (or those with an average mark of less than 50\%).

\section{FRAMEWORK FOR ANALYSIS OF ESSAYS}

A framework for the analysis of these essays was then developed. The framework had, firstly, to draw attention to those features of the students ' essays which were likely to have resulted in the mark it was awarded, and secondly, to enable us to compare patterns across both languages. In the end, we found the broad categories of ARGUMENT, SYNTACTIC STRUCTURE and REGISTER were most useful as an organizing framework for the analysis. However, it should be noted that these categories overlap and the divisions between them are somewhat artificial. We arrived at these categories through a process of analyzing the kinds of factors we felt had resulted in some essays being graded as good and others as poor and then viewing these through different theoretical lenses. 


\section{Argument}

By 'argument' we refer to the ability of the student to construct an argument to support his or her position in response to the essay question. While we did not expect a formal academic essay, we expected the students to be able to state their opinions in response to the question and to justify and substantiate that opinion in some way. The essays were evaluated against a model of argument that privileges a relatively linear organization of ideas with similar ideas grouped together. We recognize that the ability of students to produce this genre depends on whether they have been taught this kind of writing at school and that this genre is transmitted and sustained by institutions with particular ideological orientations. It is, in Gee's (1990) terms, a secondary discourse, or a more specialized literacy learned through social institutions beyond the family, to which students are apprenticed through their schooling. Despite the ideological nature of this standard, we used it as a benchmark as it is the 'standard' against which students are currently evaluated and against which success or failure is currently determined.

A concept which we found useful in analyzing the overall flow of information within the essays was that of COHERENCE. By coherence, we mean the extent to which, in Halliday's words, a text 'hangs together' (Halliday \& Hasan, 1989: 48) or the extent to which the preceding sequence of sentences provides a context with which the following can cohere. Coherence depends on the reader/listener's ability to infer relations between sections of continuous texts (Brown \& Yule, 1983). Breakdowns in coherence arise when the writer/speaker has incorrectly judged what background knowledge he or she shares with the audience and omits certain essential propositions. They can also occur as a result of ambiguous or vague statements (Brown \& Yule, 1983: 247-250) or when the inferences which are necessary for the processing of the text can only be made with difficulty or not at all (Brown \& Yule, 1983: 256-270). Breakdowns can also occur when what Brown and Yule call the 'flow of information' or the development of topic is unclear.

For the purposes of examining the topic development, we typed and presented the essays in the following way: we wrote each main clause, including any subordinate and embedded clauses on a new line. Adverbial clauses in the English essays were also given their own 'lines' on the basis that they are less tightly integrated with the main clause and do not qualify nominal groups. We then focused on the grammatical subject of each 'line' which enabled us to track the development of the topic and identify the extent to which students were able to control the switching between topics and achieve a coherent flow of information.

\section{Syntactic Structures}

The previous category focused on student writing at the level of text - it examined the flow of information - and began to focus on student writing at the level of sentence - namely the subject of each main clause. This section focuses in more detail on the sentence.

An important contribution to coherence comes from COHESION, which Halliday defines as 'the set of linguistic resources that every language has ... for linking one part of a text to another' (Halliday \& Hasan, 1989:48). These resources include, amongst others, CONJUNCTIONS and REFERENCE. Breakdowns in meaning occur when writers/speakers do not sufficiently signal the relationships between clauses through the use of appropriate conjunctions, or when the referents of referring expressions are unclear or confusing. 
We also looked at students' use of punctuation, in particular, the extent to which they used capital letters and full stops to mark sentence boundaries.

\section{Register}

Halliday defines Register as the variety of language corresponding to the variety of situation or the way the context of situation of any event affects the way language is used. He describes it as a 'semantic concept', the result of a particular configuration of meanings that are typically associated with a particular situation (Halliday \& Hasan, 1989: 38). He adds that it must also include the 'expressions, the lexico-grammatical and phonological features, that typically accompany or realize these meanings' (Halliday \& Hasan, 1989: 39), or in Eggins's words: 'Register theory describes the impact of dimensions of the immediate context of situation of a language event on the way language is used' (Eggins, 1994: 9).

Under this broad category, we considered how writers sought to persuade their readers of their position and how they projected themselves into their texts. Halliday refers to these as aspects of 'tenor', and Hyland (1999) as 'writer stance'; other theorists speak about 'voice'. Essentially we were concerned with the ways in which students used language and a range of rhetorical strategies or styles to communicate their arguments. For example, we considered how the writer attempted to engage the reader through use of personal pronouns, imperatives and rhetorical questions, as well as what Hyland refers to as 'hedges' and 'emphatics' (Hyland, 1999: 101). Hedges often signal tentativeness and allow for the writer's admission of readers' face needs and of community norms through the use of words like possible, might, perhaps and believe. Emphatics signal certainty and can be used to mark involvement with the topic or solidarity with the reader through phrases such as it is obvious, definitely and of course.

We evaluated the extent to which the students had achieved an appropriate level of formality in their writing for the task and context. For example, we considered the use of metaphorical or deep 1 Xhosa as opposed to a more everyday variety, or the extent to which their writing in English was closer to a typically informal spoken variety or a more formal written one. We also looked at the range of vocabulary used in relation to the above.

We could have commented on other aspects of writing, such as the use of tenses, concord agreement, spelling and so on, but these seemed less significant to the communication of meaning in these essays and are therefore not discussed. However, it is highly likely that future work on the analysis of different kinds of writing tasks will necessitate modifications to the framework, particularly as one 'moves' up the levels of tertiary study.

\section{RESULTS}

\section{Cross-linguistic performance}

1 'Deep' Xhosa is a variety of Xhosa mostly spoken in rural areas which does not make use of code-mixing. It is valued because it is viewed by the speakers of the language as a carrier of Xhosa culture. Mixed Xhosa is viewed with a certain ambivalence by its mostly urban speakers: as a corruption of pure Xhosa, but at the same time, as a marker of modernity and 'cool' urban culture. 
1. Good writers in Xhosa were generally good writers in English as well, and vice versa. In other words, good writers performed well in both languages and got similar marks for both essays. Working with the sample of 60 essays, we calculated the average mark differential (or difference between their two marks) as 4.7. 32 students scored better in their Xhosa essay, and 28 in their English essay - thus one cannot say that overall people performed better in their first language.

The good students tended to perform fairly evenly across both languages with a tendency to perform better in their English essays. Of the 17 students who scored 60\% or more in their English essays, the average mark differential was 4.5. Of these 17, 12 scored better in their English essays than in their Xhosa essays. Of the 10 who scored $60 \%$ or above for their Xhosa essays, 8 also scored $60 \%$ or above for their English essays, and their average mark differential was 4.7 .

However, the weaker students tended to perform better in their Xhosa essays - of the 17 who failed their English essays, 16 scored better in their Xhosa essays with an average differential of 7.8. Of the 4 who failed their Xhosa essay, only one scored better for their English essay and their average mark differential was 4.4.

\section{Analysis of Xhosa essays}

The analysis of the essays is presented under the headings: Argument in the Xhosa essays, and Register in the Xhosa essays. Translations of the Xhosa essays are also given. It should be noted that it is impossible to give an accurate sense of the students' writing in the translation, especially as we were trying to keep as close the original Xhosa text. Some of the awkwardness of phrasing in the English versions is a result of this translation

\section{Argument in the Xhosa essays}

The aspect of writing which seemed to be most important in distinguishing the good Xhosa essays from the weak ones was the students' ability to answer the question appropriately, show an awareness of different perspectives on the issue and argue convincingly for their position. The weaker essays tended to have one or more of the following problems:

- the question and/or key concepts had been misunderstood

- the essay failed to provide convincing arguments to support the position adopted

- the students simply listed a few points, without elaboration

- the links between ideas were not clear

- the points were repeated and recycled throughout the essay, without much elaboration or development.

\section{Register in the Xhosa essays}

Aspects of register were also a determining factor for the Xhosa essays. Good writers employed a more formal register characterized by the use of 'deep' or metaphorical Xhosa. The weaker writers used a more informal everyday variety of Xhosa, and if they used deep Xhosa words, they tended to use them inappropriately or inaccurately. 
Secondly, the better writers projected themselves more confidently into their texts. They boldly stated their positions and more readily engaged the reader in support of their arguments.

Consider the first few paragraphs of the Xhosa essay of a good writer (Student A) for which she scored an average of $63 \%$.

Ndicinga okokuba kubalulekile ukuba abantu basebenzise isiXhosa esisulengekileyo xa bekumabonakude nasesidlangalaleni.

Xa ungumXhosa ibalulekile emaXhoseni into yokuba uzidle ngobuXhosa bakho. 2

Kwaye xa umntu ephakathi kwabantu abangamaXhosa makuthethwe isiXhosa hayi esixutyiweyo.

Xa ujonga ngoku thina bantu batsha asisixabisanga isiXhosa

Kanti ukuba besisithetha yonke imihla ngesisazi.

Ukuba abantu banokuqhubekeka bexuba xa bethetha kungahambeka siphele isiXhosa.

Kungahambeka abantu bangasazi mpela.

Ndicinga okokuba omakhulu bethu nookhokho bethu mabasifundise isiXhosa

loonto yenza ukuba singaziwa isiXhosa.

English translation:

I think that it is important for people to use pure Xhosa on TV and in public. 1 When you are Xhosa it is important for you to be proud about your Xhosaness 2 Also if a person is among Xhosa people Xhosa should be used not mixed. 3

If you can look now we young people do not regard/value/respect Xhosa 4 and we do not know it. 5 Whereas if we were speaking it everyday we would have known it. 6 If people would continue mixing when talking Xhosa would eventually disappear.

Eventually people would lose it totally.

I think that our grandmothers and grandfathers should teach us Xhosa 9 because in schools where we spend most of the time we do not speak it now these days

and that causes Xhosa to be unpopular.

In this essay, the writer presents her position fluently and persuasively. She uses a number of deep Xhosa words which give weight to her argument and enable her to use an appropriately formal register. Examples here include 'asisixabisange' meaning 'to regard/value/respect' (line 4), the use of the adverb 'mpela' in line 7 and the phrase 'omakhulu bethu nookhokho' which, if translated literally, means 'our grandmothers and ancestors' (line 9). She also projects herself confidently into the text. The strategies she uses to achieve this include the assertion of her membership of the Xhosa speaking community and the emphatic use of 'ndicinga' or 'I think' at 
the opening of the essay and in line 8. A second strategy she uses is to engage her reader in a dialogue with the use of the personal pronouns, 'ndi' (I) and 'thina' (we) and phrases such as 'thina bantu batsha' or 'we young people' (line 4) and the direct address: 'Xa ujonga' or 'If you can look now' (line 4).

Compare this with an essay at the other end of the scale (Student B) for which the student was awarded an average mark of $38 \%$. Besides the fact that he has misunderstood the questions (he presents arguments for multilingualism and does not address the pure versus mixed Xhosa debate), his register resembles that of a typically informal spoken variety of Xhosa.

Hayi makungasetyenziswa isiXhosa sodwa. 1

makusetyenziswe nezinye izithetho 2

kuba ayilunganga into yokuba kuthethwe isiXhosa sodwa. 3

Thina maXhosa siyafuna ukuzazi izithetho zolunye uhlanga 4

kuba imisebenzi iyasihambisa isisa kwamanye amazwe 5

ekufuneka ungathethi isiXhosa. 6

Kunye nabantu abamhlophe bayakufuna ukuthetha isiXhosa 7

kuba asilo lwimi labo. 8

Yilento kufuneka ukuba kungathethwa isiXhosa sodwa. 9

Kufuneke into yokuba thetha ( iEnglish) isingesi okanye iLARTIN 10

ube unga yazi nokuba kuyiwa ngaphi 11

ube uyazi ukuba uzakuyithetha lento izakube ithethwa phaya 12

mna ngokunokwam ndithi ilungile into yokuba kuthethwe zonke izithetho ekufaneleke

uzithethile 13

ozokukwazi ukuthi ungaxakeki emazweni 14

kaloku akufuneki uthethe isiXhosa lonke ixesha 15

kuba zikhona indawo eziza kuba nabantu abahlukeneyo 16

kube kufuneka uthethe zonke izithetho zalapha emzantsi Afrika. 17

English translation:

No, Xhosa should not be the only language used. 1

Other speeches should be used as well 2

because it is not right or fair to speak Xhosa only. 3

We Xhosas would like to know speeches of other nation 4

because work forces us to move to other countries 5

where you won't be expected to speak Xhosa 6

$\begin{array}{ll}\text { and also white people are interested in speaking Xhosa } & 7\end{array}$

because it is not their language (mother tongue) 8

This is why it is not proper to speak Xhosa only. 9

Be expected to speak english or LARTIN 10

and you be confused 11

but you are sure that you will speak what is spoken there 12

and also I myself am saying that it is right for all languages to be spoken that you are

supposed to speak 13 
so that you do not find yourself in trouble in other 'unfamiliar countries' remember it is not beneficial/helpful/desirable for you to speak Xhosa all the time

because there are places which will have people who come from different backgrounds

Words and phrases which signal an informal spoken register include 'mna ngokunokwam ndithi' (line 13) and 'kaloku' in line 15. He uses no examples of deep Xhosa. Some of his syntactic structures suggest a very informal register, such as the unclear referencing of 'phaya' (there) in line 12 and the missing subject of line 10. Note the very long sentences consisting of clauses chained together with conjunctions, such as 'kuba' (because), kunye (and (also)) and 'ube' (meanwhile/whereas/at the same time). This essay also illustrates a point we made earlier about the way in which the weaker essays tend to simply list ideas without making explicit the links between them or without signalling syntactically a shift in topic - see lines $6 \& 7$.

In terms of our analytical framework, syntax was less of an issue for the Xhosa essays, and this, of course, can be explained by the fact that it is the students' first language and they have a first language speaker's control over the grammar. However, it was an issue for the English essays, and it is to the analysis of these that we now turn.

\section{Analysis of English essays}

The analysis of the English essays is presented under the following headings:

- Argument in the English essays

- Sentence level writing in the English essays

- Register in the English essays

\section{Argument in the English essays}

In terms of argument and register, similar patterns to the Xhosa essays can be noted in the English essays. The better essays were better structured and argued. The writers of the weaker essays either misunderstood the topic, demonstrated a limited grasp of the content and/or did not organise their ideas according to the norms of academic argument. These writers also showed a lack of familiarity with the norms of academic writing, for example, they began their essays with a YES or a NO answer, but then did not restate the question. Note that this was also a feature of the weaker Xhosa essays.

The weaker essays were also characterized by failures of coherence. An analysis of the subject of the clauses shows this up, as, in a number of clauses, the subjects are missing. This can perhaps be partly explained by the fact that in Xhosa, the subject is not always present and when it is absent, its meaning is implied or carried by the concord. Consider the following example of a very weak essay in English:

Student C

Yes, Because we come from different schools

other schools they use to learn English, Xhosa and Afrikaans 2

and other they use English, Xhosa

others they use to learn Xhosa only 
and other's they use to learn English only.

and is good to communicate with foreign people's.

Even more jobs they need someone who can speak English

and also assist you from different people who speak different languages especially here in South Africa

and help you to know educational things and more subjects

The topics of lines 6, 8 and 9 are unclear as the subjects are missing. $\mathrm{s}$ a result, the meaning is difficult to extract giving rise to an impression of incoherence. Notice once again the limited vocabulary range (for example, the overuse of 'other/s'), the repetitive sentence structures and the chaining together of clauses with co-ordinating conjuctions, predominantly 'and'. The repetition of the subject as in 'others they' may be the result of transfer from Xhosa, or a feature of informal, often spoken, discourse.

\section{Sentence level writing in the English essays}

Syntax proved to be a category of equivalent importance to argument for the English essays. The better essays showed a greater control over the syntax of the language which enabled the writer to say what he or she wished to say confidently, persuasively and fluently. The weaker essays typically displayed a range of sentence level problems, of which we have identified the following as most important in explaining breakdowns in communication:

- problems of cohesion

- failure to mark sentence boundaries.

Problems of cohesion

As noted earlier, cohesion is an aspect of coherence, but of a more syntactic nature. In the weaker English essays, we particularly noted problems with the following features:

a) the confusing use of referring expressions, where the referent is unclear, ambiguous or not stated, and

b) the range of conjunctions and other strategies used to signal the relationships between clauses.

An example of a) is illustrated by lines $6 \& 7$ in the first two paragraphs of Student D's essay. The referent of 'they' and 'their' is unclear, and the use of 'he' in line 12 is odd as 'he' , a singular pronoun, refers back to the plural referent, 'other people'.

Universities in South Africa can use english only

because english is the easiest language every body can understand.

If you look at Xhosa people

they can easily know English

and afrikaans people can know it.

At the sametime they can use other languages

because other schools use their languages

and not relie in english, 
because sometimes other people didn't know your language 10

and if you talk with English 11

he can know.

The weaker essays relied heavily on conjunctions (in particular, and, but, because and if) to link clauses, and, as noted earlier, this frequently gives rise to an informal register that more closely resembles that of informal spoken English. The better essays also made good use of these conjunctions. However, they used a wider range of strategies to link clauses, such as the subordination and embedding of clauses.

Sentence boundaries and punctuation

It was obvious to us that the failure of students to mark sentence boundaries with full stops and capital letters created problems for the markers. Sometimes, during our analysis, it only became clear to us what students were trying to say when we began separating their sentences into clauses and presenting them on individual lines, and this often required some creative inferencing on our part! It is very difficult to make sense of a text when it is characterized by unmarked sentence boundaries, missing subjects and, sometimes, illegible handwriting. These factors tend to obscure the content of the students' essays and negatively affect their mark. Consider Student C's essay written as the student wrote it without our imposed clause breaks:

Yes, Because we come from different schools other schools they use to learn English, Xhosa and Afrikaans and other they use English, Xhosa others they use to learn Xhosa only and others's they use to learn English only. and is good to communicate with foreign people's. Even more jobs they need someone who can speak English and also assist you from different people who speak different languages especially here in South Africa and help you to know educational things and more subjects especially in tertiary level they used to teach with an English. English assist with educational development especially here in South Africa.

\section{Register in the English essays}

The better essays, like the better Xhosa ones, employed a more formal register of English which was more appropriate to the context and task of the entrance essays. They were generally more confident, persuasive and fluent. Compare the first paragraph of Student A's English essay for which she was awarded a mark of $70 \%$ with that of Student D, who scored an average of $42.5 \%$ for her English essay.

Student A - English essay

I think English should be the major language

because it is the language that is common to all of the students. 2

I think everyone is more exposed in English, 3

its the only language that we can communicate well in. 4

I do believe that other languages are important 5

but English is the easiest one for everyone 6

$\begin{array}{ll}\text { its the only language that we can communicate well in. } & 7\end{array}$

I think we should continue studying in English. 8

I also think if we study with our own language 9

we would not be exposed to English, 10 
so if we speak to other people from overseas who do not understant (sic) our languages,

we wouldn't be able to communicate- $\quad 12$

If we know English 13

we would be able to communicate with other people. 14

Notice once again Student A's confident, fluent style of writing and the strategies she uses to achieve this: a clear positioning of herself as a speaker of a language other than English, as well as a member of the global community, the frequent use of 'I think' for emphasis and the use of the personal pronouns 'I' and 'we' and, later in the essay, rhetorical questions to directly engage her reader:

If for example in a class there are ten students or eleven with all the official languages and one lecture.

How is the lecture going to teach 25

I mean what language would she use. 26

Would she use her own language $\quad 27$

if she is Afrikaans. 28

If she did 29

what about other students. 30

Student D's essay (see previous section), on the other hand, reflects a more limited knowledge of English. For example, she has overused the word, 'know' to mean 'to understand' as well as 'to know'. Note that these two meanings are carried by the single Xhosa word, 'ukwazi'. Her clauses are short and repetitive and she relies on the syntactic structure clause + conjunction + clause to structure her sentences. The structure $X$ can know English/it is repeated five times in the short four paragraph essay and she relies on the conjunctions and, but, because and if to join her sentences. It is interesting to note that these English conjunctions are popularly used in code-mixed Xhosa.

One can argue that the register of Student D's essay is closer to that of a typically informal spoken variety of English. According to Chafe (1982:38-39), one of the characteristics of the informal spoken English data he studied was the stringing together of what he calls idea units both without connectives and through the frequent use of the coordinating conjunctions, of which the most common was and. This particular student is able to adopt a more formal register when writing in Xhosa, but many of the weaker students are not, which suggests that some of them may not have access to this secondary discourse in any language.

\section{Generic style}

Lastly, it is interesting to note that sometimes a particular rhetorical style adopted by a writer in one language, such as the use of repetition or foregrounding, was evident in his or her writing in the other language. This, together with the comparison of mark differentials we commented on earlier, suggests that writing skill and individual style are cross-linguistic or generic characteristics. The cross-linguistic similarities of Student A have already been commented on in previous sections. In the examples which follow, student E uses foregrounding to bring particular topics into prominence in the sentence in both his English and Xhosa essays. Note the foregrounding of the topics, 'English', in the English essay (line 2 ) and in the Xhosa essays, 'abazali' (line 5) and the extended nominal clause in line 15. Note 
also the foregrounding of the adverbial clauses in the English essay (lines 5, $7 \& 9$ ) and the Xhosa essay (line 17):

Student E’s English essay (70\%)

I think university should use English only at their studies.

English is one of the most used languages worldwide. 2

It would be in our disadvantage 3

for a person to learn about his/her language.

When you think about our country, $\quad 5$

we have eleven languages, $\quad 6$

if we can learn by our own languages, $\quad 7$

there would be a lot of misunderstanding to each other. 8

In the working place were you would learn after you finish your studies, 9

there would be a lot of misunderstanding to workers and the management. 10

Student E's Xhosa essay (70.5\%):

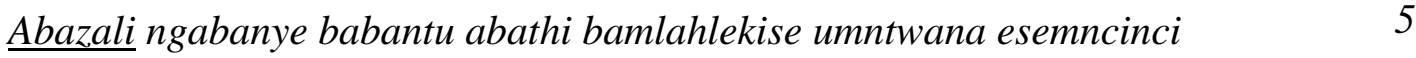

ngokuthi umntu bamthathe bayekumfaka kwizikolo zabamhlophe 6

Kweli lithi isiXhosa kufuneka usixube xa uthetha kwindawo enabantu abaninzi andivumelani nayo kwaphela 15

kuba andisiboni mna isizathu sokuba usixube isiXhosa xa uthetha nomnye umntu ongumXhosa 16

Xa uthi usixube isiXhosa nelinye ulwimi uthi uphazamise lomntu uthetha naye, 17

kuba uza kubhideka yilonto uyithetha naye 18

English translation:

Parents are also among the people who mislead a child still at a tender age 5

by taking the person and 'throw' / send him or her to white schools 6

On the question of mixing Xhosa when talking to many people I do not agree with it at all 15

because I do not see any reason why you should mix Xhosa when you are talking to another Xhosa person. 16

When you mix Xhosa and another language you distract the person you are talking $\begin{array}{ll}\text { with } & 17\end{array}$

because you will be confused by what you are talking about 18

Student F's essays also display a generic style. She uses a very repetitive sentence structure in both languages relying heavily on 'you' as her subject and topic which though rather monotonous, serves to give her essays a coherent feel.

Student F's English essay (65\%)

whereas when you use any official language like Xhosa 11

you choose to study Xhosa only. 12

maybe you choose Xhosa 13 
if you are Xhosa speaking

all your subjects have to be lectured in Xhosa 15

and you forgot all about english, $\quad 16$

when you are finish in your final year $\quad 17$

you don't find a job 18

all jobs you found need people with a pure english 19

$\begin{array}{ll}\text { and you end up regreting yourself. } & 20\end{array}$

Student F's Xhosa essay (62.5\%)

Uthi ke ukuba ungummelwane wabelungu ubabone bekuxabisile 16

kuba nawe ubaxabisile uyasixuba isiXhosa sakho 17

nabo ubave besithi 'Hallow Mmelwane' 18

nawe ke uzive unemincili 19

English translation:

And if you are a neighbour of white people they will also respect you 16

because you also respect them because you mix your Xhosa 17

and sometimes you hear them saying 'Hallo neighbour' 18

and you too feel great or happy 19

\section{CONCLUSIONS AND FUTURE RESEARCH DIRECTIONS}

In sum, there seem to be three categories of factors that differentiate the good essays from the weaker ones, as summarized by the framework for analysis we developed:

- familiarity with the genre and conventions of academic argument

- ability to use a more formal written register

- control over the grammar of the language

The first two were significant for essays in both languages, whereas the last one proved more significant for the analysis of essays in English.

The first is obviously a schooling issue, as are the second and the third to a certain extent. Space does not permit a full discussion of the social and contextual aspects which may help to explain or give insight into the nature of these issues, but research points to factors such as the failure of the schooling system and language teaching to develop a range of secondary discourse types, the development of varieties of code-mixed Xhosa and English, the effects of apartheid education, and so on. (Refer to Gough, 1996, Gough and Bock, 2001, for a fuller discussion.) It would have been interesting to interview the 'good writers' in this sample to explore those experiences they feel had helped them to develop as writers of English and Xhosa. Similarly, it would have been interesting to speak with the students who performed better in one language only and to find out their stories?

This research reports on one particular writing task performed in a particular context at a particular point in time. Our framework now needs to be tested against other samples of writing in a range of contexts spanning a number of different levels to establish how useful it 
is in profiling typical problems and strengths in student writing. We anticipate that the nature of problems and the kinds of strengths will change as the level, task and context change, and that this will require modifications to the framework. But we hope that at the end of the day, we will have a detailed understanding of why student writing passes or fails, and what kinds of problems lead to communication breakdowns, and that this in turn will inform pedagogic interventions and writing programmes.

\section{REFERENCES}

BERKENKOTTER, C, AND TN HUCKIN. 1995. Genre knowledge in disciplinary communication, New Jersey: Lawrence Erlbaum Associates.

BROWN, G AND YULE, G. 1983. Discourse Analysis. Cambridge: Cambridge University Press.

CANDLIN, CN AND K HYLAND. (eds.) 1999. Writing: Texts, processes and practices. London: Longman.

CHAFE, W. 1982. Integration and involvement in speaking, writing and oral literature. In Tannen, D (ed.), Spoken and written anguage: Exploring orality and literacy. Norwood, NJ: Ablex. Pages 35-53.

COOK, G. 1989. Discourse. Oxford: Oxford University Press.

EGGINS, S. 1994. An introduction to Systemic Functional Linguistics. London: Pinter.

GEE, JP. 1990. Social linguistics and literacies: Ideology in discourses. London: Falmer Press.

GOUGH, D. 1996. Black English in South Africa. In De Klerk, V (ed.), Focus on South Africa. Amsterdam: John Benjamins Publishing Company: 53-77.

GOUGH, D. AND Z BOCK. 2001. Alternative perspectives on orality, literacy and education: A view from South Africa. Journal of Multilingual \& Multicultural Development, 22(2): 95-111.

HALLIDAY, MAK AND R HASAN. 1989. Language, context, and text: aspects of language in a social-semiotic perspective. Oxford: Oxford University Press

HASAN, R. 1996. Literacy, everyday talk and society. In HASAN, R AND GWILLIAMS (eds.) Literacy in society. London: Longman: 77-424.

HEATH, S B. 1983. Ways with Words. Cambridge University Press.

HYLAND, K. 1999. Disciplinary discourses: writer stance in research articles. In C N Candlin \& K Hyland (eds.), Writing: Texts, processes and practices. . London: Longman: .62-81IVANIC, R. 1998. Writing and identity: The discoursal construction of identity in academic writing. Amsterdam: John Benjamins Publishing Company. 
LEA, MR., AND B STREET. 1999. Writing as academic literacies: understanding textual practices in higher education. In Candlin, CN \& K Hyland (Eds.), Writing: Texts, processes and practices. London: Longman: 62-81.

Leki, I. (1995). Coping strategies of ESL students in writing tasks across the curriculum. TESOL Quarterly, 29(2): 345-368.

STREET, B. 1995. Social literacies: Critical approaches to literacy in development, ethnography and education. London: Longman

TAYLOR, G, B BALLARD, V BEASLEY, HK BOCK, J CLANCHY, \& $\mathrm{P}$ NIGHTINGALE. (eds) 1988. Literacy by degrees. Milton Keynes: The Society for Research into Higher Education \& The Open University.

\section{Biographic note}

Zannie Bock teaches in the Department of Linguistics at the University of the Western Cape. Until September 2002, Phakamani Dadlana also taught in the department. He now works for Maskew Miller Longman (email: PhakamaniD@mml.co.za and zbock@uwc.ac.za) 